\title{
INTERPRETATION OF HYDROGEOLOGICAL FUNCTIONING OF A HIGH KARST PLATEAU USING THE KARSYS APPROACH: THE CASE OF TRNOVSKO-BANJŠKA PLANOTA (SLOVENIA)
}

\author{
INTERPRATACIJA DELOVANJA VODONOSNIKA VISOKEGA \\ KRASA Z UPORABO MODELA KARSYS: PRIMER TRNOVSKO- \\ BANJŠKE PLANOTE (SLOVENIJA)
}

\author{
Janez TURK ${ }^{1}$, Arnauld MALARD ${ }^{2}$, Pierre-Yves JEANNIN ${ }^{2}$, Jonathan VOUILLAMOZ ${ }^{2}$, Jean MASINI', \\ Metka PETRIČ ${ }^{1}$, Franci GABROVŠEK ${ }^{1}$, Nataša RAVBAR ${ }^{1}$, Tadej SLABE ${ }^{1}$
}

\begin{abstract}
UDC 556.3:551.435.8(497.4)

Janez Turk, Arnauld Malard, Pierre-Yves Jeannin, Jonathan Vouillamoz, Jean Masini, Metka Petrič, Franci Gabrovšek, Nataša Ravbar, Tadej Slabe: Interpretation of hydrogeological functioning of a high karst plateau using the KARSYS approach: the case of Trnovsko-Banjška planota (Slovenia)

The high karst plateau of Trnovsko-Banjška planota is one of the most important reservoirs of karst water in Slovenia. Almost all important karst springs in this area are captured for water supply. A sustainable management of this source of groundwater is of strategic importance, not only as drinking water supply but also for the economy. For these reasons, many hydrogeological monitoring studies have been carried out over the last decades. However, no consistent regional overview of the hydrogeological functioning of Trnovsko-Banjška planota was available and we decided to study this area with more direct approach based on 3D geological and hydrogeological models. The so called KARSYS approach was developed in Switzerland and applied primarily to characterize groundwater reserves within a karst massif, and to sketch the main flow-paths carrying groundwater from recharge areas to the respective springs. The delineation of spring catchment areas in karst regions was better defined and interactions between catchments were interpreted. These results can be used to improve the management of karst waters in the studied area.

Key words: KARSYS, karst aquifer, groundwater flow, storage, catchment delineation, water management.
\end{abstract}

Izvleček UDC 556.3:551.435.8(497.4) Janez Turk, Arnauld Malard, Pierre-Yves Jeannin, Jonathan Vouillamoz, Jean Masini, Metka Petrič, Franci Gabrovšek, Nataša Ravbar, Tadej Slabe: Interpratacija delovanja vodonosnika visokega krasa $z$ uporabo modela KARSYS: primer Trnovsko-Banjške planote (Slovenija)

Visoki kras Trnovsko-Banjške planote predstavlja enega najpomembnejših vodonosnih sistemov v Sloveniji. Skoraj vsi večji izviri na območju so zajeti za vodooskrbo, zato je učinkovito in trajnostno upravljanje vodonosnika strateško pomembno tako $\mathrm{z}$ vidika vodooskrbe, kot tudi z ekonomskega vidika. V zadnjih desetletjih je bilo na območju narejenih veliko hidrogeoloških študij in opazovanj. Še vedno pa manjka sinteza teh rezultatov, ki bi nazorno prikazala značilnosti in dinamiko vodonosnika. To vrzel do v dobri meri zapolnjujejo rezultati predstavljeni v tem članku. Uporabili smo model KARSYS, ki so ga sicer prvi razvili in uporabili v Švici in z njim ocenili zaloge podzemne vode in smeri glavnih tokov med območji napajanja in izviri. $\mathrm{Z}$ modelom smo določili tudi meje napajalnih zaledij glavnih izvirov. Rezultati bodo omogočili še učinkovitejše upravljanje s kraškimi vodami na tem območju.

Ključne besede: KARSYS, kraški vodonosnik, tok podzemne vode, skladiščenje, določitev meja napajalnih zaledij, upravljanje $\mathrm{z}$ vodami.

\footnotetext{
${ }^{1}$ Karst Research Institute ZRC SAZU, Titov trg 2, 6230 Postojna, Slovenija. Slovenian National Building and Civil Engineering Institute, Dimičeva 12, 1000 Ljubljana, Slovenija.

${ }^{2}$ Swiss Institute for Speleology and Karst Studies ISSKA, Post Box 818, 2301 La Chaux-de-Fonds, Switzerland.

Received/Prejeto: 21.01 .13
} 


\section{INTRODUCTION}

Water stored in karst aquifers represents an important source of drinking water, not only in Slovenia but in many countries around the world. In Slovenia already half of the population (one million) is supplied from karst aquifers (Turk 2010). Water from these aquifers is also used for irrigation and for producing electricity (hydropower plants). For all these reasons, water resources in Slovenia must be managed in a sustainable way (Bakalowicz 2005, Ravbar 2007).

This study is focused on the area of Trnovsko Banjška planota (high karst plateau), which is probably the most important reservoir of karst groundwater in Slovenia. The extension of the karst plateau is about $490 \mathrm{~km}^{2}$ (Fig. 1).

Karst water emerges at five big springs (three permanent, two temporary) at the foothill of Trnovsko - Banjška planota (Hubelj, Mrzlek, Podroteja, Divje jezero, Lijak). Their maximal discharges are larger than $30 \mathrm{~m}^{3} / \mathrm{s}$ (except of Podroteja spring). From these, three permanent springs are captured for water supply. Tens of smaller karst springs are also captured for local water supply. Generally, all settlement and towns in the surrounding of the Trnovsko - Banjška planota get domestic water from the main karst aquifer, including the biggest town in this (western) part of Slovenia - Nova Gorica with 13'500 inhabitants.

However, settlements and villages (with around 8000 habitants) located at the top of the high karst plateau may represent a potential risk of pollution of the springs (Albreht et al. 1993). Anthropogenic activities in the recharge area, such as traffic, agriculture, forestry, tourism, industry etc. may endanger groundwater quality.

Several surveys and monitoring studies have been carried out in the area in order to better characterize spring waters and to maintain water quality at the springs. Intense hydrologic and hydrogeologic surveys were carried out between sixties and nineties of last century, when karst systems were delineated by means of geological mapping, tracer tests and water balance calculations. Spring hydrographs and chemographs have been monitored and analyzed (Placer \& Čar 1974, Habič 1982, Habič 1987, Habič \& Čar 1987, Kranjc 1997, Janež et al. 1997, Trček 2003).

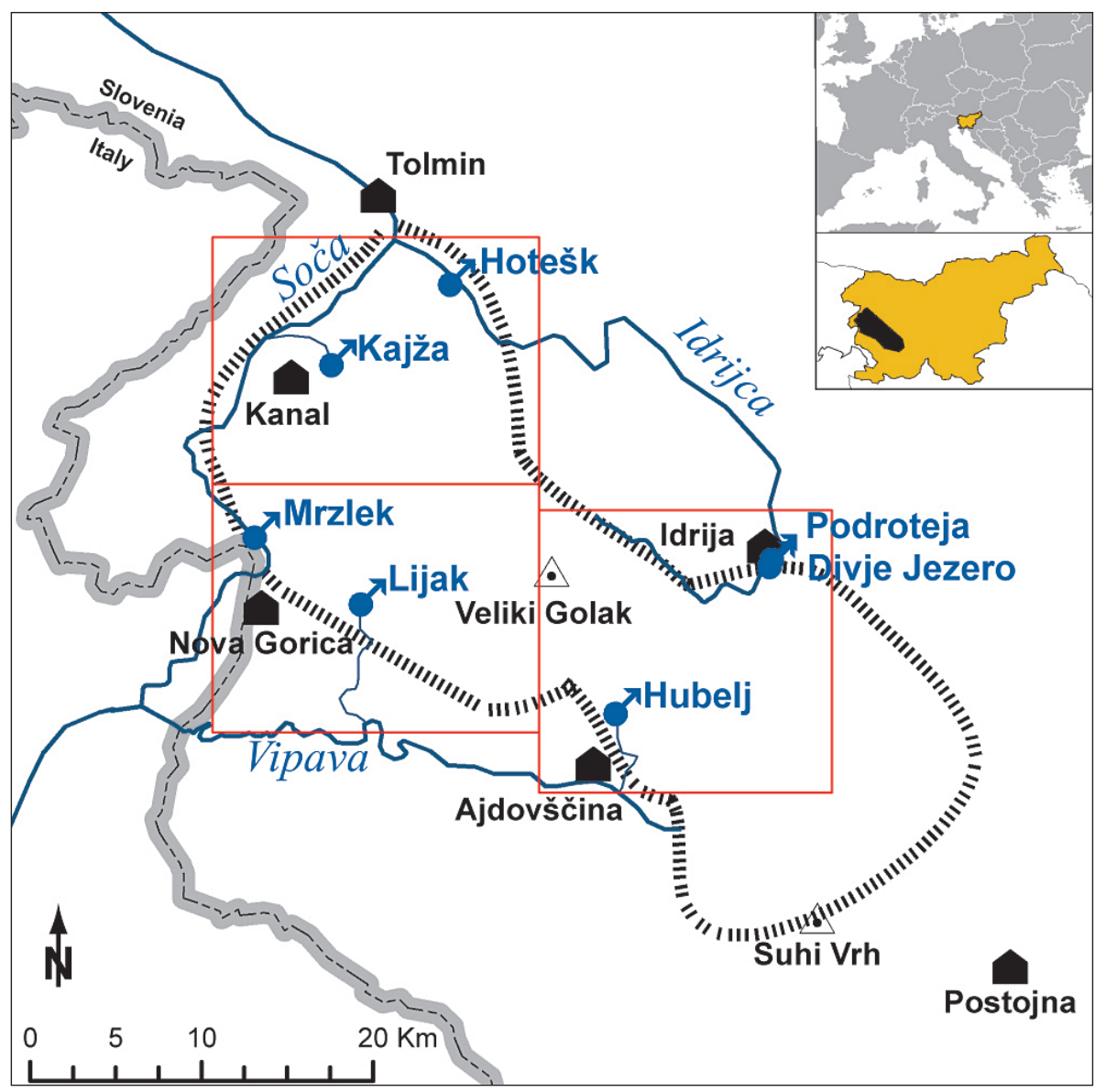

Fig. 1. Map of the study area. High Dinaric karst plateau is delineated with dash line. Trnovsko - Banjška planota, a part of this plateau, was divided into three areas (rectangulars with red frames), which were modeled separately. The main springs in study area are given in blue. 
All these "standard" surveys provide a first overview of the geological and hydrogeological context but they do not describe the functioning of karst systems as a whole (on regional scale). Moreover several questions remained open such as the delineation of the catchment area of the respective springs.

For this reason, the Karst Research Institute (Slovenia) decided to work together with the Swiss Institute for Speleology and Karst Studies in order to apply the so called "KARSYS" approach. One strength of this approach is to synthesize all existing data into a single iterative 3D model, leading to a visualization of the hydrogeological functioning of the aquifer. Resulting maps and 3D models can easily be understood not only by hydrogeologists, but also by environmental managers, administrators and other technical or non-technical staff. This approach is therefore useful for improving the management of karst water resources (Jeannin et al. 2012).

\section{STUDY AREA}

Trnovsko - Banjška planota means plateau is situated in SW part of Slovenia. The surface of the plateau lies mostly between 800 and $1200 \mathrm{~m}$ a.s.l., with the highest peak at 1495 m - Mali Golak (Habič 1987).

The high karst plateau is under influence of an alpine climate, while the Vipava valley (south of the plateau) shows a submediterranean climate and other valleys around the plateau show transitional submediterranean climate. The mean annual temperature on the plateau of Trnovsko - Banjška planota ranges from 7 to $9^{\circ}$ C. Mean annual precipitation ranges from 2000 to 3000 mm (Pristov 1997).

\section{GEOLOGY}

The Trnovsko - Banjška planota is built of Upper Triassic to Eocene rocks, as presented on Fig. 2.

Upper Triassic Norian-Rhetian dolomite (so called "Main dolomite") is greatly extended in the northern part of the area. In stratigraphically higher parts, grey layered dolomite passes into light grey layered organogenic Dachstein limestone.

Jurassic rocks consist of limestones and dolomites. Total thickness of Jurassic rocks reaches 1000 to $1500 \mathrm{~m}$.

Cretaceous is developed in characteristic carbonate facies. Total thickness of Cretaceous limestones is between 2500 and $3000 \mathrm{~m}$.

Paleocene and Eocene flysch rocks are lying discordantly on older stratigrafic units. Flysch rocks consist of alternation of marlstones, quartz sandstones and marly limestones (Čar 1997, Čar 2010).

\section{HYDROGEOLOGICAL CHARACTERISTICS}

The main karst aquifer of Trnovsko - Banjška planota is composed by Jurassic and Cretaceous limestones (Fig. 2).

Fig. 2. Stratigraphic pile of Trnovsko - Banjška planota (modified after Janež et al. 1997).

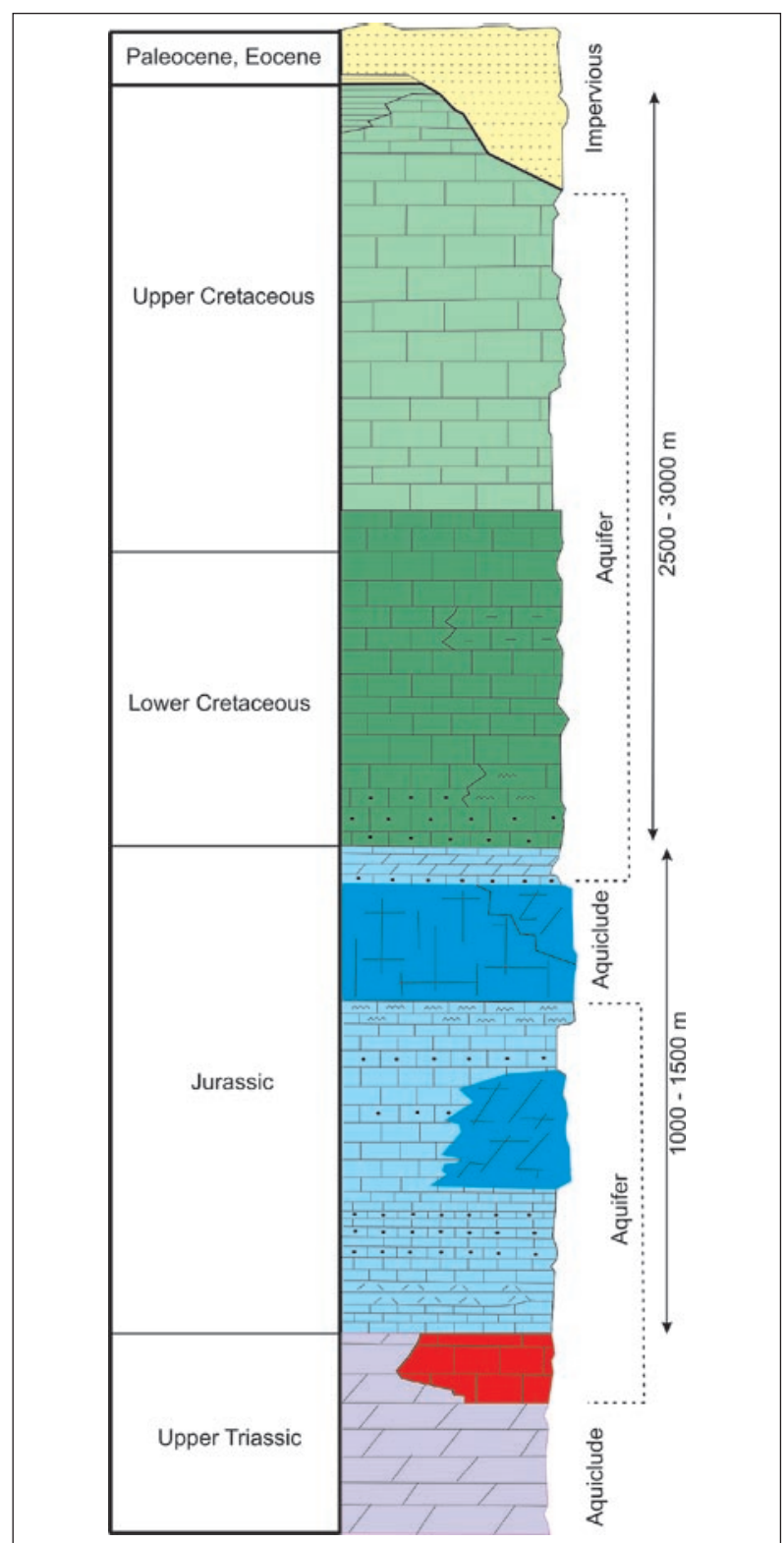


Tab. 1. Stratigraphic units that built the Trnovsko - Banjška planota, their porosity (matrix, fissure, conduit) and permeability.

\begin{tabular}{l|l|l}
\hline Stratigraphic unit & Type of porosity & Degree of permeability \\
\hline Eocene and Paleocene flysch & matrix & Low pervious \\
\hline Cretaceous carbonate breccias & Triple (including conduit) & Well pervious - aquifer \\
\hline Cretaceous limestone & Triple (including conduit) & Well pervious - aquifer \\
\hline Jurassic limestone & Triple (including conduit) & Well pervious - aquifer \\
\hline Jurassic dolomite & Dual (matrix and fissure) & Medium pervious - aquiclude \\
\hline Upper Triassic limestone & Triple (including conduit) & Well pervious - aquifer \\
\hline Upper Triassic dolomite & Dual (matrix and fissure) & Medium pervious - aquiclude \\
\hline clastic rocks of Triassic age & matrix & Low pervious \\
\hline
\end{tabular}

Tab. 2. Main springs of Trnovsko - Banjška planota and their characteristics. Discharge rate are often estimated.

\begin{tabular}{l|l|l|l|l|l|l}
\hline Spring & Coord $x(m)$ & Coord $y(m)$ & $\begin{array}{l}\text { Elevation } \\
(m \text { a.s.l. })\end{array}$ & $\begin{array}{l}\text { Min discharge } \\
\left(\mathrm{m}^{3} / \mathrm{s}\right)\end{array}$ & $\begin{array}{l}\text { Max discharge } \\
\left(\mathrm{m}^{3} / \mathrm{s}\right)\end{array}$ & Flow-regime \\
\hline Mrzlek & 395040 & 95433 & 77 & 0.5 & 40 & perenial \\
\hline Lijak & 401200 & 91380 & 105 & 0 & 32.5 & temporary \\
\hline Hubelj & 416080 & 84500 & 240 & $0.03-0.04$ & 60 & perenial \\
\hline Divje jezero & 425070 & 93590 & 330 & 0 & 60 & temporary \\
\hline Podroteja & 425189 & 94010 & 330 & 0.2 & $\mathrm{a} \mathrm{few} \mathrm{m}^{3} / \mathrm{s}$ & perenial \\
\hline Kajža & 399500 & 105375 & 191 & 0.007 & 2 & perenial \\
\hline Hotešk & 406400 & 110080 & 270 & 0.03 & 6 & perenial \\
\hline
\end{tabular}

Dolomitic layers (mostly aquicludes) are present in the upper part of the Jurassic series and in Upper Triassic. The real aquifer basement is constituted of flysch and also dolomite. Hydrogeological aspect of stratigraphic units is presented in Tab. 1.

From a hydrogeological point of view, Trnovsko Banjška planota is a relatively well delineated mountainous karst area bounded by lower, non-karstic margin regions. Impervious flysch surrounds karstified limestone of the high karst plateau in the southern, western and eastern sides, acting as a partial hydrogeological barrier. In the north, the plateau is surrounded by relatively less pervious clastic rocks (Upper Triassic) (Janež et al. 1997).

\section{MAIN SPRINGS}

Only the biggest and most important springs are discussed in the present paper (Tab. 2, Fig. 3). All are springs with a maximal discharge exceeding $1 \mathrm{~m}^{3} / \mathrm{s}$. They are usually situated at or close to the lowest outcrops of the impervious barrier, or at the local erosional base level (Kranjc 1997).

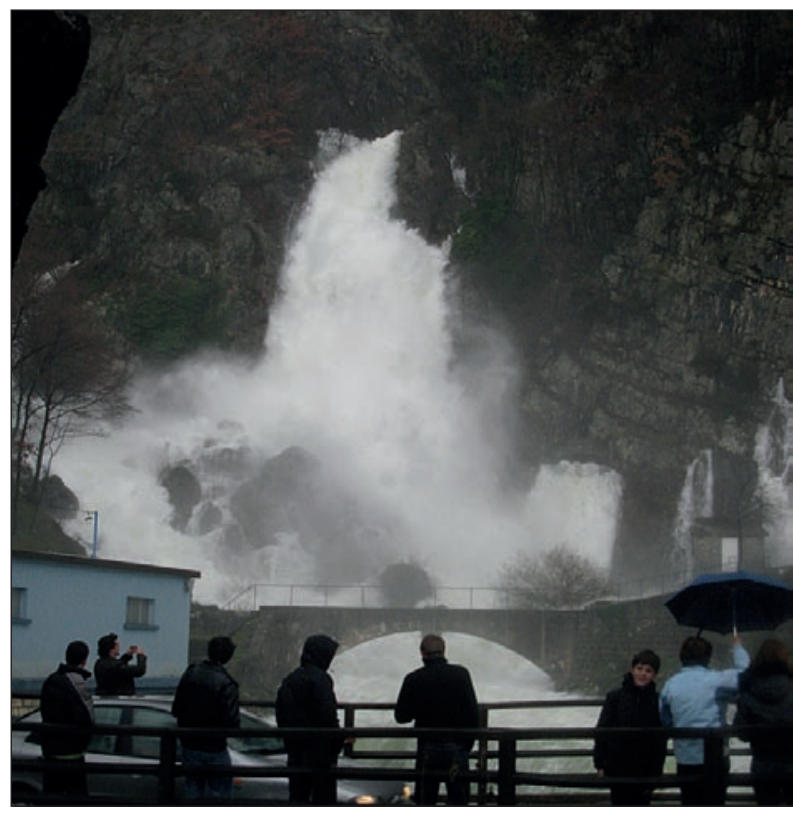

Fig. 3. Hubelj spring at I JH water (photo Katja Željan).

\section{CONCEPTUAL 3D MODEL - BASE OF THE KARSYS APPROACH}

KARSYS approach was developed at Swiss Institute for Speleology and Karst Studies. The approach is based on the construction of a 3D conceptual hydrogeological model that combines geological and hydrogeological data.

Because the studied area (Trnovsko - Banjška planota) is relatively large, it was divided into three rectan- gle regions: eastern part of Trnovski gozd area $(19,050 \mathrm{x}$ $14,460 \mathrm{~m}$ ), western part of Trnovski gozd area with the most southern part of the Banjšice (19,050 x 14,420 m) and Banjšice (17,070 x 16,500 m) (Fig. 1). 3D geology of each of the three regions was modeled separately and all obtained 3D geological models were later merged 
into one model representing entire Trnovsko - Banjška planota.

The most precise geological maps were selected for the construction of the 3D geological model. All existing cross-sections were collected from the available literature. This data-set was incorporated into a software dedicated to $3 \mathrm{D}$ geological modeling (Geomodeller software).

The obtained geological model was mainly based on the geological map 1:50,000 (Albreht et al. 1993). However, this map does not cover all the margins of the study area, and other geological maps were also taken into consideration, such as a Basic geological map 1:100,000 (Buser 1986) and a geological map 1:25,000 dedicated to the area of Idrija (Mlakar and Čar 2010). All together 14 cross-sections collected from various authors (Placer \& Čar 1974, Buser 1986, Albreht et al. 1993, Janež et al. 1997, Mlakar \& Čar 2010) have been used to built the 3D geological model.

The obtained 3D geological model defines the geometry of the studied aquifer. The bottom of the aquifer is limited by impervious lithological units and the top by land-surface topography or by impervious confining units. All stratigraphic units between the bottom and the top of the aquifer exhibiting any contrast in hydrogeological characteristics should be taken into consideration. Units distinguished in the model of Trnovsko - Banjška planota are indicated in Tab. 1 .

The study area is strongly affected by tectonic processes (alternation of complex over-thrusted structures) (Placer \& Čar 1974, Placer 1981, Zagoda 2004), and the main characteristic of the respective tectonic units were also considered. The autochthonous basement is overlained by several overthrusted tectonic units (Tab. 3, Fig. 4). These tectonic units were also included into 3D geological model.

Several important strike slip faults cross the area, and two of them are considered to play a major role for controlling the hydrogeological behavior of the studied system. These are Predjama-Avče fault and the Zala fault (Fig. 4). Both of them were integrated in the model.
The obtained 3D model can be improved by adding data such as cave observations and borehole logs (if any does exist). This kind of data may help to define the position of the aquifer bottom and the boundaries between different lithological units more precisely (Jeannin et al. 2012). Some rare data from caves and a few boreholes (Čar \& Gospodarič 1988, Janež 1992) could be included in the study area. Data from boreholes are not easilly available, for this reason only a few boreholes can be considered. Borehole in direct vicinity of Lijak spring is described in literature (Čar \& Gospodarič 1988, Janež 1992). Lithological contact between aquifere formations (limestone) and aquifer basement (flysch) was defined by geoelectricity at four locations. Applied geological cross-

Table 3. Main tectonic units in Trnovsko - Banjška planota and their stratigraphy.

\begin{tabular}{l|l}
\hline Tectonic unit & Stratigraphic layers \\
\hline Trnovo nappe & Triassic to Eocene \\
\hline Čekovnik interjacent slice & Upper Triassic \\
\hline Koševnik interjacent slice & Cretaceous \\
\hline Hrušica nappe & Upper Triassic to Eocene \\
\hline
\end{tabular}

sections drawn by Placer \& Čar (1974) are based also on data obtained by geoelectricity.

The resulting $3 \mathrm{D}$ geological model is presented on Fig. 5. The next step of the KARSYS approach was to use it as a base for interpreting a 3D hydrogeological model. All three 3D geological models were thus exported and merged. All major karst springs and other hydrological features (surface streams, siphon in caves, etc.) were implemented into this model. Cinema $4 \mathrm{D}^{\circ}$ software was utilized for this step.

The construction of the hydrogeological model is based on simple but liable hydraulics principles (Jeannin et al. 2012, Malard et al. 2012): (1) the aquifer volume below the main perrenial spring is water saturated; (2) the hydraulic gradient in the saturated zone (low water) is almost flat as a result of high transmissivity of karst rocks (limestone). Gradient of $0.1 \%$, or $1 \%$ at most, is assumed for defining the top of the phreatic zone.

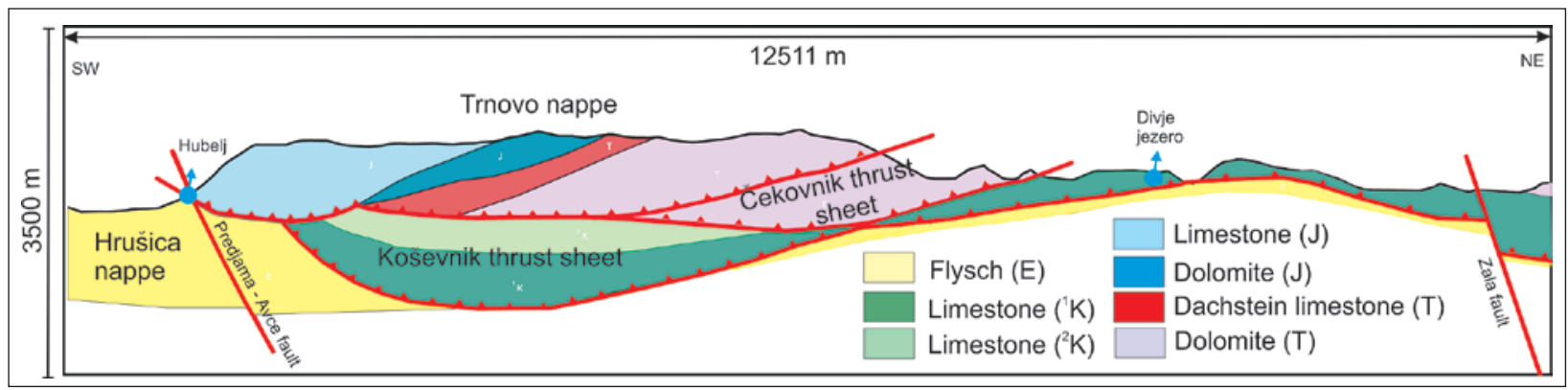

Figure 4. Cross-section through Hubelj and Divje jezero springs showing the major tectonic units included in the model. 


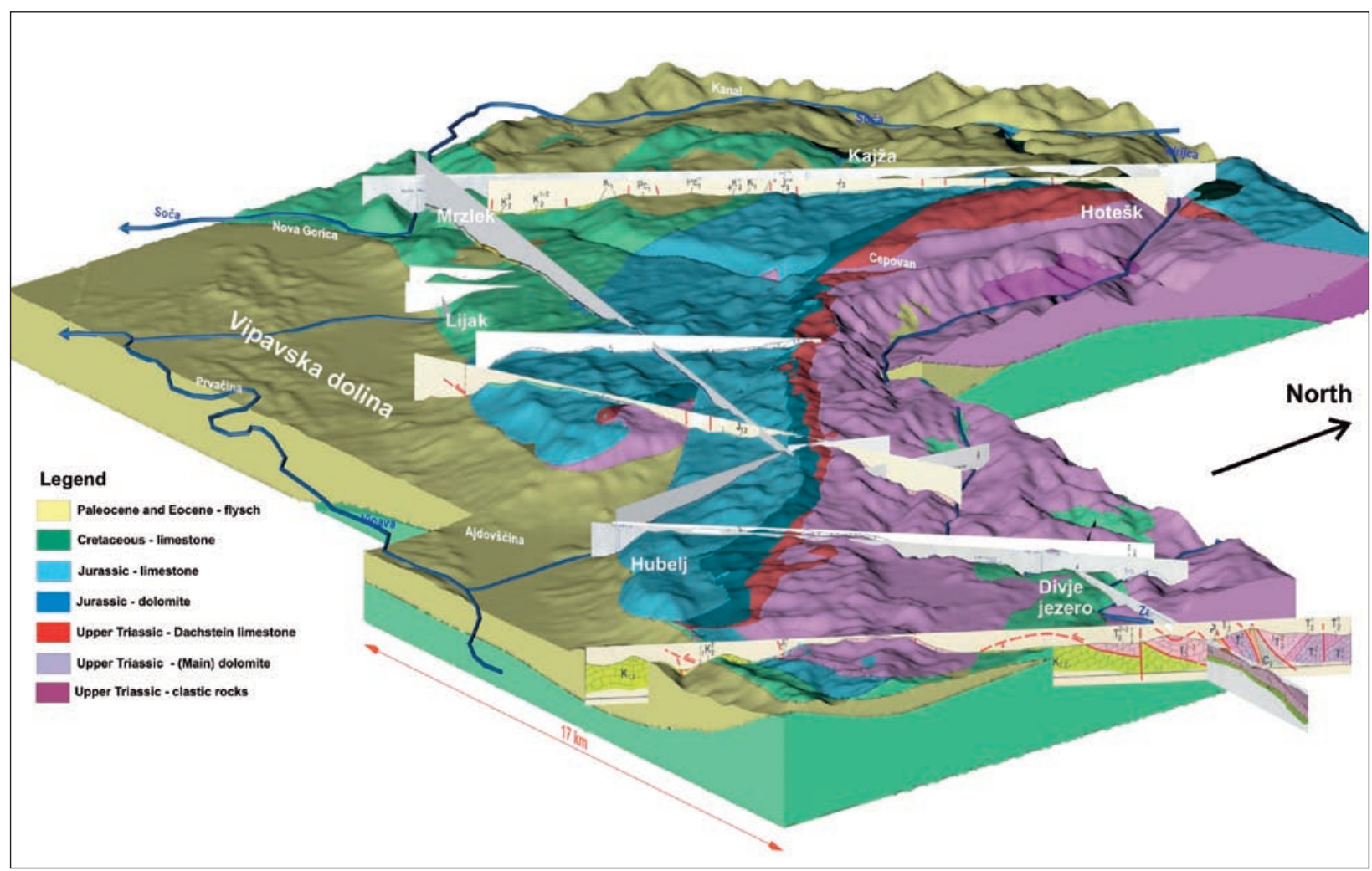

Figure 5. Perspective view from the 3D geological model of the discussed area and geological cross-sections used.

Groundwater reservoirs can thus be assumed in the following way: the hydraulic gradient (water table or top of the saturated zone within karst conduits) is gently steeping upstream from the main perennial springs. The extension of the saturated zone can thus be sketched by prolonging a plan from the spring through the karst media, until it crosses the top of the aquifer basement. Without data, the minimum possible gradient (zero) is asumed meaning that the extension of the saturated zone defined in this way is minimal. This hypothesis is assumed for low water conditions.

Hydraulic gradients can be much higher at high water conditions. To assess the gradient at such conditions, piezometric data should ideally be available at several locations within the aquifer. Consistent data are usually obtained in caves or boreholes. Habečkov brezen is one of rare caves in the area, where groundwater fluctuations can be directly observed (Habe \& Hribar Štefančič 1955, Čar \& Zagoda 2005). However, due to the lack of this kind of data for Trnovsko - Banjška planota high water conditions are not discussed in this paper.

Considering the volume of saturated parts of the aquifer (below of the groundwater table), the groundwater volume stored within the massif can be estimated (according to a value of effective porosity of the rock), what remains a future work. Unfortunately data about the ef- ficient porosity of the Cretaceous and Jurassic limestone are not available in the literature for this area.

After the identification of groundwater reservoirs, the position of the main flow-paths within unsaturated (vadose flows) and saturated zone (phreatic flows) can be assessed from the model. Flow through the unsaturated zone can be assumed as vertical, unless impervious layers are present. Once flow reaches the aquifer bottom (aquiclude) it then drains along the dip of this unit, until it reaches the saturated zone. Groundwater flows in the saturated zone follows more or less a straight line towards the spring.

The resulting model thus provides a description of karst groundwater reservoirs, confined and unconfined areas as well as the position of the main underground flowpaths. The combination of these observations, as well as their interaction (i.e. identification of water exchanges at a threshold) provides concrete elements to delineate their catchment boundaries (Vouillamoz et al. 2011). Diffluent areas (areas recharging two or more underground systems / springs) can be quite precisely defined by this approach. The resulting hypothetical hydrogeological conceptual model can also be validated by including results of existing (or new) tracer tests. 


\section{RESULTS}

\section{OVERVIEW AT REGIONAL SCALE}

\section{Groundwater bodies and catchment areas}

The model provides for the first time an overview of the distribution of groundwater reserves within the aquifer of Trnovsko - Banjška planota (Fig. 6). Moreover, it depicts the hydrogeological functioning of the aquifer on the regional scale, pointing out some unexpected relationships. of Mrzlek - Lijak and Hubelj springs. In this area, the perched groundwater body is expected to overflow to the east towards Hubelj spring and to the west towards the Mrzlek - Lijak springs.

\section{Effects of the tectonic setting}

The Predjama-Avče fault (SE - NW direction) seems to have very important role on the distribution and shape

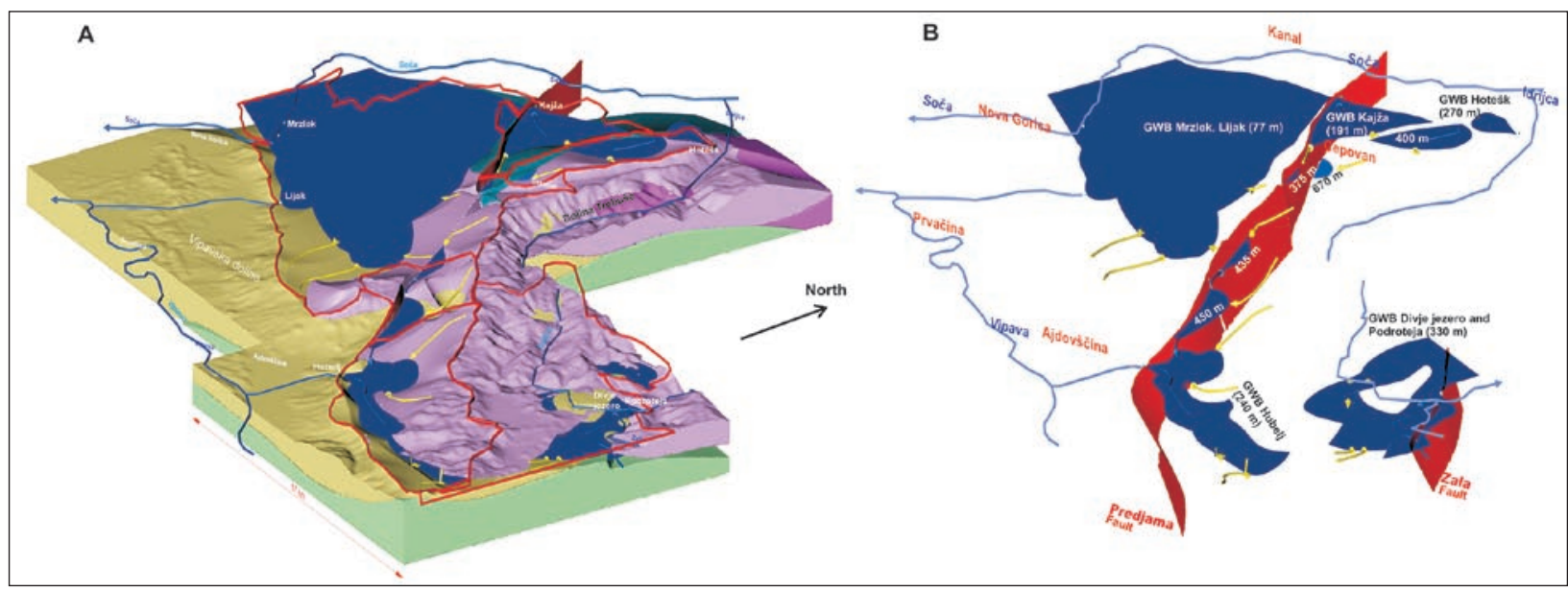

Figure 6. Hydrogeological model of the Trnovsko - Banjška planota. LEFT:Aquifer formations are not visible in this figure, which depicts only aquiclude formations surrounding aquifers and damming groundwater reservoirs. Catchment areas of the main springs (red lines) were delineated based on the assessment of flow-paths (yellow arrows = flows in unsaturated zone, blue arrows =flows in saturated zone). See also legend in Figure 5. RIGHT: Same figure showing only the groundwater reservoirs and vadose flow-paths. Note that groundwater reservoirs of Divje jezero and Mrzlek systems expand out of the model.

Concerning groundwater reservoirs in Trnovsko Banjška planota (Fig. 6) the model evidences the presence of a large groundwater body in the western part of the massif, and a series of smaller, partly perched bodies in the central part. The most extended groundwater reservoir is connected to the system of Mrzlek (permanent) and Lijak (temporary) springs.

The smaller groundwater bodies do not occur only directly upstream of permanent springs, but also as perched groundwater reservoirs, which existence has been previously totally ignored. This means that in some regions vadose water drains to perched groundwater reservoirs with an underground outlet (threshold) from which water flows further downstream in vadose channels towards another groundwater body. The model also indicates that these conditions may significantly change according to the water level (e.g. in high water conditions).

Groundwater flows in unsaturated and saturated zones of the aquifer in low water conditions are depicted by the model. Based on this data, catchment areas of studied systems (springs) were delineated (Fig. 6). The model evidenced a divergent region between the systems of local groundwater reservoirs (Figure 6). The displacement induced by the strike slip movement leads to the creation of small perched reservoirs developed in depressions along the fault. The diffluence reservoir mentioned in the previous paragraph is one of them.

Also crushed zone developed along some parts of Predjama-Avče fault and along Zala fault play an important role on regional hydrogeology. Such zones seems to be impervious, as reported by several authors (Albreht et al. 1993, Janež et al. 1997). They seem to make a barrier between the systems of Divje jezero - Podroteja, Mrzlek - Lijak and Kajža.

\section{Interpretation of flowpaths and their prediction}

Underground connections between surface and phreatic zones (groundwater reservoirs) are relatively well defined by the $3 \mathrm{D}$ model. In practice it means that from every point at the surface of the model, we can predict the direction of surface and especially underground drainage. Based on the model, we can not only evaluate and balance results of some previous tracer tests, we can also predict the suspected path of new ones. However, it 


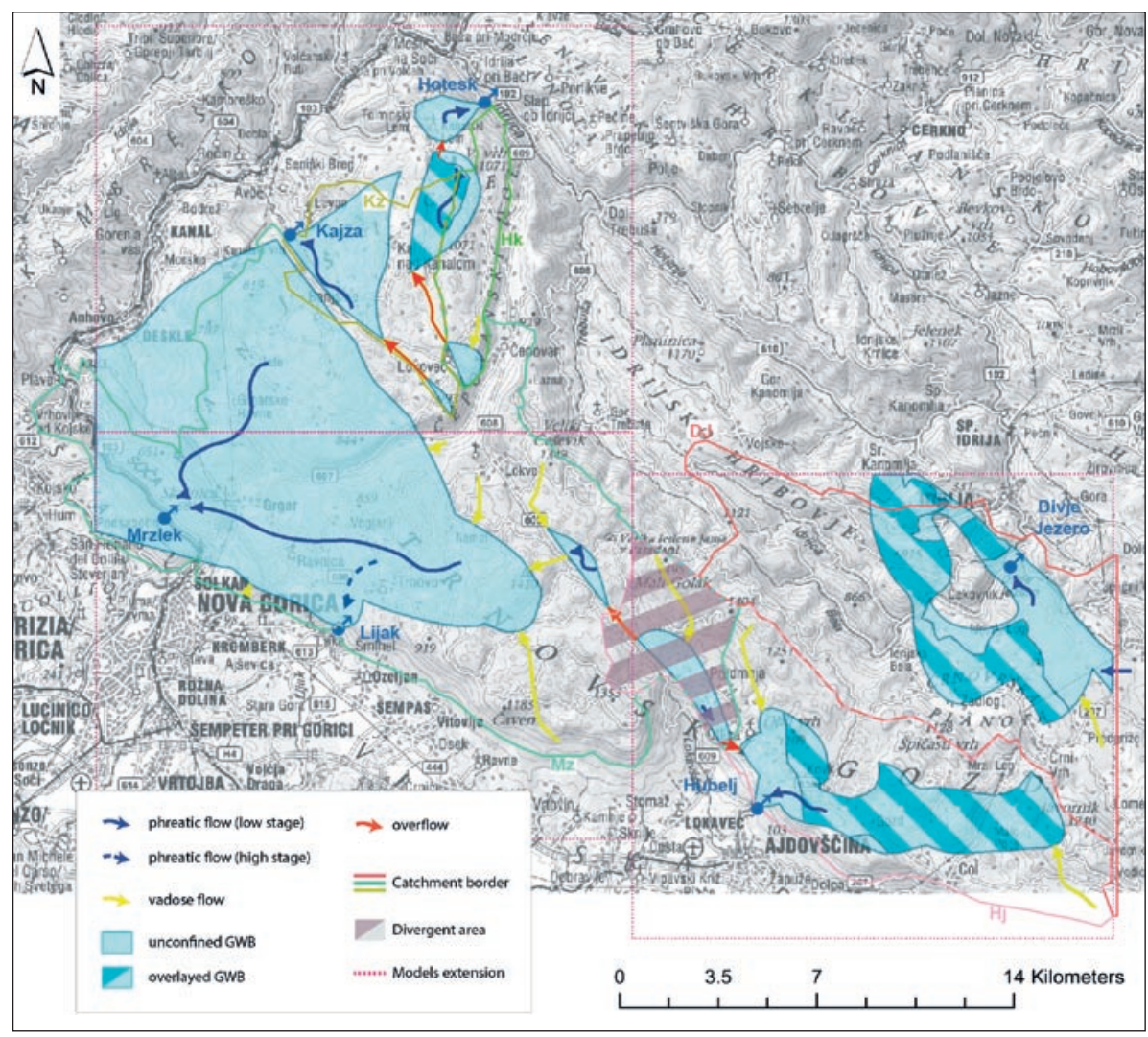

Figure 7. Karst hydrogeological map of the Trnovsko - Banjška planota showing the location and extension of groundwater reservoirs (blue areas) and catchment areas of the respective springs. The divergent area between Hubelj and Mrzlek systems is indicated.

must never be forgotten that the model is a simplification of real conditions in the fields and that new data will not fit all model predictions, i.e. that the model will have to be improved continuously with the acquisition of new data.

\section{LOCAL SCALE SETTINGS}

In this part, hydrogeological conditions derived from the model are described for the five main karst flow systems identified in this study.

\section{System of Hubelj spring}

Hubelj spring represents the outlet of karst waters stored in SE part of the Trnovsko - Banjška planota. As evidenced by the model (Fig. 6 to 8 ), the aquifer develops in two tectonic units (both of limestone composition) in this region. Both units are separated by a intercalation of Triassic dolomite (relatively less permeable) related to the thrusts structure (Fig. $8 \mathrm{~B}$ ). The boundary with the neighbour aquifer feeding the Divje Jezero and Podroteja springs is well defined. The Cretaceous aquifer (green)

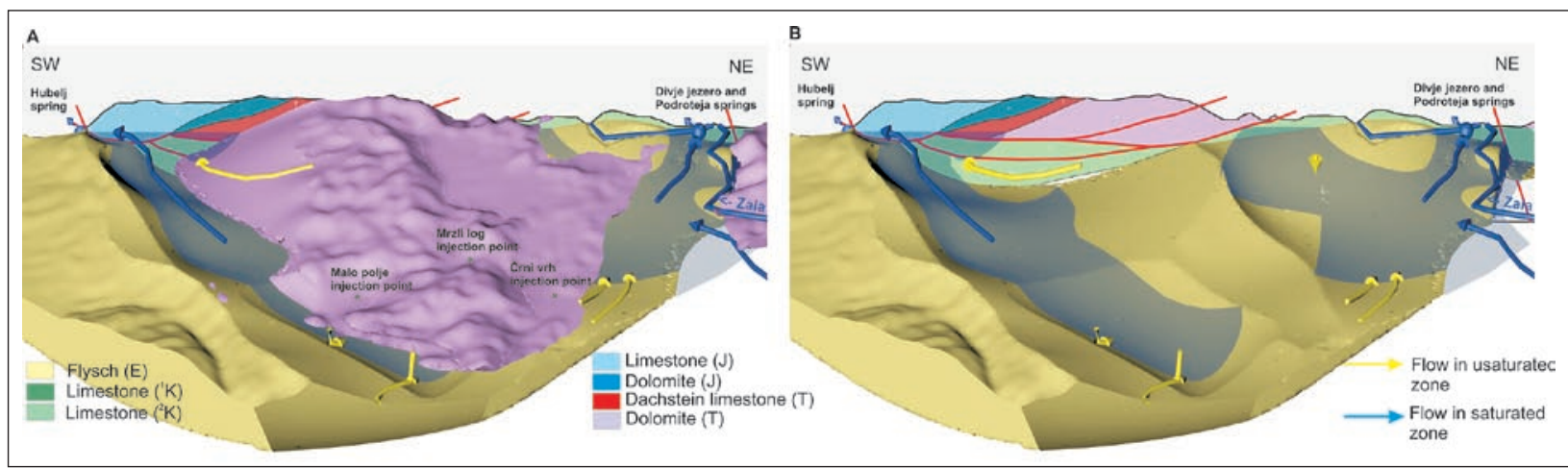

Figure 8. Groundwater reservoirs of Hubelj and Divje jezero - Podroteja springs. Aquifer formations (limestone) are not represented on the figure where only aquiclude formations are visible. Groundwater reservoirs of both springs extend below relatively low pervious Triassic dolomite (rose formation visible on the left figure) and above the flysch formation (beige). The Triassic dolomite has been removed on the right figure (B) to display the entire extension of groundwater reservoirs. Groundwater bodies of Hubelj and Divje jezero - Podroteja springs are clearly separated by the top of the flysch formation. 


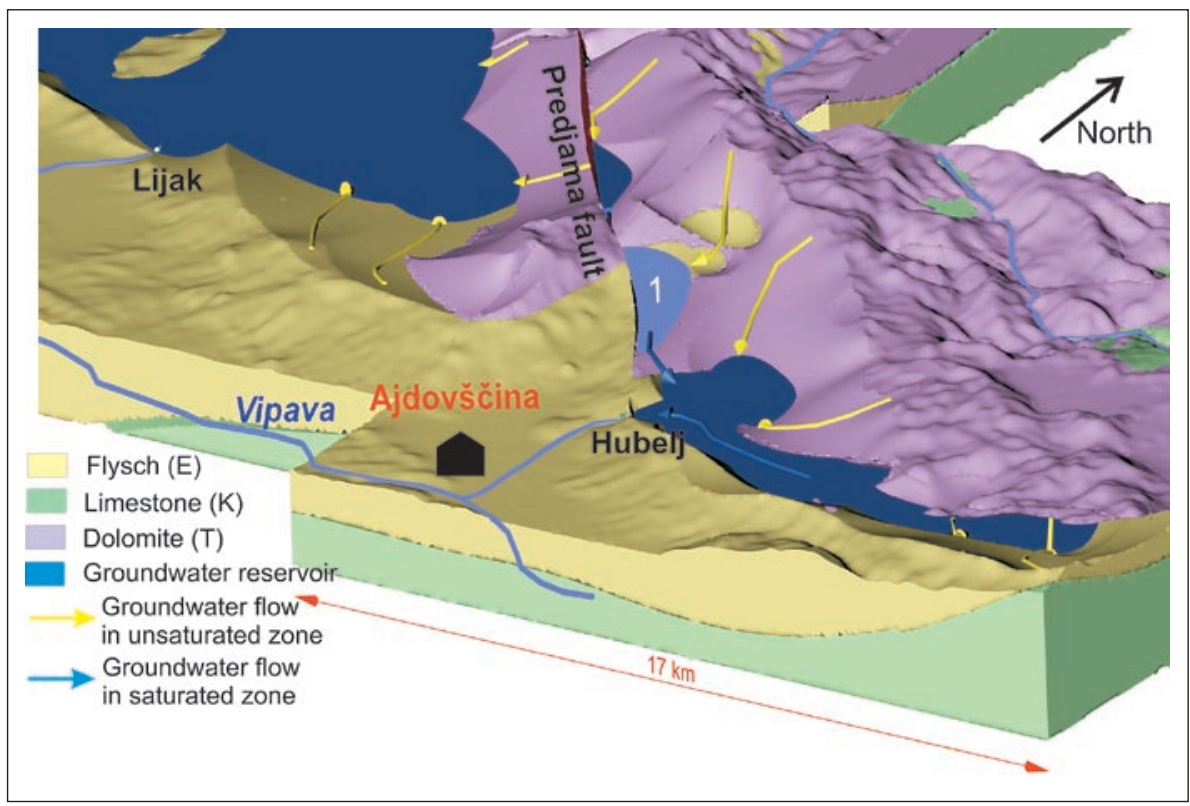

Figure 9. Diffluent area between Hubelj and Mrzlek springs is related to a perched groundwater reservoir (marked with "1") overflowing mainly towards Hubelj spring, but also towards Mrzlek (and Lijak).

appears to be completly pinched between the Triassic dolomite and the lower flysch, which is the basement of the aquifer. Such geological structure does not allow any bifurcation between Hubelj and Divje Jezero - Podroteja systems.

North-West of the Hubelj spring groundwater reservoir a relatively small groundwater reservoir presumably exist in the catchment area of Hubelj (Fig. 6B, see also Fig. 9). This perched reservoir is linked with local topography of the aquifer basis (induced by the abovementioned strike slip fault). Water table in this reservoir should reach an elevation of $450 \mathrm{~m}$ a.s.l. and should drain to the East over a threshold of Triassic dolomite, as indicated by the model (Fig. 9). Water is expected to drain further downstream through a system of conduits towards the main groundwater reservoir of Hubelj spring (with a water table at $240 \mathrm{~m}$ a.s.l. at low water conditions) (Fig. 6 and Fig. 9).

Fig. 7 depicts the catchment area of the Hubelj spring deduced from the model. It was estimated to $94 \mathrm{~km}^{2}$ (see also Fig. 6A, Tab. 4), what is larger than previous estimations, which ranged between $50 \mathrm{~km}^{2}$ and $80 \mathrm{~km}^{2}$ (Albreht et al. 1993, Kranjc 1997).

\section{System Mrzlek - Lijak}

The aquifer feeding Mrzlek spring (and Lijak at high water conditions) is mainly developed within the Jurassic and the Cretaceous limestone of Trnovo nappe. The crushed zone related to Predjama-Avče fault sets the NE limit of the saturated zone of this aquifer. This groundwater reservoir probably extends out of the model towards the West, and for this reason, total extension cannot be assessed with the model (Fig. 6 and 7).
Mrzlek shows the largest catchment area of all springs of the Trnovsko - Banjška planota. It was estimated at least $217 \mathrm{~km}^{2}$ (Fig. 6, Tab. 4). Around $80 \%$ of this catchment is karstic (autogenic) and $20 \%$ allogenic.

Assessment of high water conditions indicated that the catchment area of the Mrzlek and Lijak springs is even larger when water raises in the karst aquifer. In these conditions water from Hubelj system overflows towards Mrzlek-Lijak as already discussed. The diffluent area seems to cover around $20 \mathrm{~km}^{2}$ (Fig. 7).

\section{System Divje jezero - Podroteja}

Divje jezero is a Vauclusian spring developed in Cretaceous rocks that lie discordantly on top of impervious flysch (aquifer basement). The southern border, with Hubelj system is well defined in the model, as already discussed. The North-Western border of the phreatic zone is delineated by the crushed zone of Zala fault. The Northern and Eastern borders are at the margin of the model and remain vague for this reason (Fig. 6 to 8).

The catchment area of Divje jezero and Podroteja springs seems to exceed $100 \mathrm{~km}^{2}$. It covers not only Trnovsko - Banjška planota, but also other karst areas, that were not included into 3D model - especially the area of Hotedršica (Gospodarič and Habič 1976) in the East. Previous estimations of total catchment area were ranged between $65 \mathrm{~km}^{2}$ (Placer \& Čar 1974) to $113 \mathrm{~km}^{2}$ (Kranjc 1997).

\section{Hotešk system}

The saturated zone of the Hotešk system is developed in Dachstein limestone (Upper Triassic), which is surrounded by relatively less permeable dolomite. Three 
Table 4. Characteristics of the main karst springs catchments of the Trnovsko - Banjška planota.

\begin{tabular}{l|c|c|c|c}
\hline Spring & $\begin{array}{c}\text { Catchment } \\
\text { area }\left(\mathbf{k m}^{2}\right)\end{array}$ & $\begin{array}{c}\text { Karstic } \\
\text { autogenic (\%) }\end{array}$ & $\begin{array}{c}\text { Covered } \\
\text { karst (\%) }\end{array}$ & $\begin{array}{c}\text { Non Karstic } \\
\text { allogenic (\%) }\end{array}$ \\
\hline Mrzlek & 217 & 79 & 2 & 19 \\
\hline Hubelj & 94 & 59 & 2 & 39 \\
\hline Kajža & 29 & 54 & 0 & 46 \\
\hline Divje Jezero & 7107 & $21^{*}$ & $0^{*}$ & $79^{*}$ \\
\hline Hotešk & 15 & 76 & 0 & 24 \\
\hline
\end{tabular}

* Values are based on catchment area included in the modeled part $\left(107 \mathrm{~km}^{2}\right)$. The total catchment area may be larger.

groundwater reservoirs presumably feed the Hotešk spring (Fig. 6 and 7).

The catchment area of Hotešk spring was estimated to $15 \mathrm{~km}^{2}$ (Tab. 4 and Fig. 7). It is mainly autogenic.

\section{Kajža system}

The saturated zone of Kajža system is located in Jurassic and Cretaceous limestones. The PredjamaAvče crushed zone (impervious) divides the Kajža system from the Mrzlek system (Fig. 6 and 7).

The catchment of the Kajža spring covers an area of $29 \mathrm{~km}^{2}$ (Tab. 4 and Fig. 7), what is much more than the $7 \mathrm{~km}^{2}$ estimated by Janež \& Čar (1990). It should however be emphasized here that the proposed catchment contributes not only to Kajža spring, but also to other small springs in the vicinity, all emerging in Avšček valley.

\section{DISCUSSION}

\section{Reliability of the model}

In this work it was naturally attempted to construct a 3D model as reliable as possible. However, the reliability depends on several factors, especially on quality and quantity of input data: only consistent geological data can provide consistent results at the desired scale (or resolution). In the present case, geological data appeared to be quite consistent although the scale of the available documents was not very precise (1:50.000 for most of the area) and the number of geological profiles quite restricted (14 profiles). We believe that the 3D geological model is consistent and adequatly represents the overall geological structure of the massif. However, we expect that details and the exact position of all geological boundaries could not be established with a high degree of precision. The model has to be considered as imperfect and can only be used to sketch geology and hydrogeology at a regional scale.

The reliability of the hydrogeological model could be evaluated based on comparisons with results of independent surveys, especially with results of tracer tests. The comparison shows that the model is consistent at least in its central part, especially for Hubelj and Mrzlek - Lijak systems as well as for modelled part of the Divje jezero - Podroteja system.

Two examples are presented hereafter to illustrate this.

\section{EXAMPLE 1: THE DIFFLUENCE AREA BETWEEN HUBELJ AND MRZLEK - LIJAK SYSTEMS}

The diffluence area between Hubelj and Mrzlek - Lijak systems evidenced by the model was compared with re- sults from one tracer test. Tracer was injected into Belo brezno cave reappeared not only in Hubelj, but also in Mrzlek and Lijak springs. The test was conducted at high water conditions, indicating bifurcation toward two groundwater reservoirs (Kranjc 1997). The model therefore provides a reasonable explanation for this result: It indicates that water drains from Belo brezno cave (and surrounding area) toward the perched groundwater reservoir situated at elevation $450 \mathrm{~m}$ a.s.l. (Fig. 9). Because this reservoir is perched above both Hubelj and Mrzlek groundwater reservoirs, it can then hypothetically overflow towards both South-East and North-West, and recharge both reservoirs. This functioning is expected to take place mainly at high water conditions especially because, according to the (imperfect) model the threshold towards Mrzlek and Lijak is located at about $570 \mathrm{~m}$ a.s.l., which is $120 \mathrm{~m}$ higher that the threshold towards Hubelj (450 $\mathrm{m}$ a.s.l.) (Fig. 9). $120 \mathrm{~m}$ of level fluctuation is a lot, but is with the range of possible fluctuations in a massif such as Trnovsko - Banjška planota. It must not be forgotten that elevations estimated from the model may be rather imprecise.

\section{EXAMPLE 2: ZALA RIVER LEAKS}

The model suggest that the Zala River is expected to lose water along the riverbed, where it is perched above on the aquifer reservoir of the Cretaceous limestone (Fig. 6). In such a case it should feed the saturated zone of Divje jezero and Podroteja springs. This kind of recharge was proved for Podroteja spring (Habič 1972, Janež 1997). 
Precision of the model surely decreases at its margins. This is not of great significance for the Southern margin, where all aquifer formations end within the model domain. This is more critical in the Western, Eastern and North-Western margins, where groundwater reservoirs clearly expand beyond the model boundaries. Therefore, the hydrogeological sketch of the Northern parts of Banjšice area (systems of Kajža and Hotešk springs) is more uncertain, also because of a deficit of geological information in this region especially at depth. The extension of groundwater reservoirs and catchment areas in these two systems, as well as the existence of two perched groundwater reservoirs in the system of the Hotešk spring should thus be considered as hypothetical.

\section{Model resolution}

The precision of the results greatly depends on the resolution used for the construction of the 3D model. In this case a resolution of $25 \times 25 \mathrm{~m}$ has been used. As the data are often scattered and no systematically sampled, the resolution of the model was based on (i) the size of the concerned area and (ii) the accuracy of the maps and cross - sections which were implemented within the model. Even if the resolution is exactly the same everywhere within the model, the precision surely decrease from the top ( $\sim$ the surface which is approximately $1 / 50000$ ) to the depth (close to $1 / 100000$ or to $1 / 200000$ ). This precision still decreases close to the borders of the model.

\section{Tracer tests validation}

The model can be used to revisit some of the uncertain results of previous tracer tests. It can also be applied to predict the flow-paths of any future tracer test.

For example, a systematic comparison between existing tracer tests and the model indicated that some of underground connections evidenced by tracer tests were not consistent with our hydrogeological model. For example, Habič (1987) reported that a tracer (rhodamin) injected into a ponor at Črni vrh (Fig. 8), reappeared not only at Divje jezero and Podroteja springs, but also in small concentrations (traces) at Hubelj spring. The latter connection is not possible regarding the model. In this region, we expect the model to be quite liable and we would really suspect that samples collected at Hubelj were contaminated. However, if tracer results could be validated (e.g. by a new test), the model should be adjusted according to this result, implying some geological work.

Another inconsistency was observed for a tracer test linking Malo polje ponor and Divje jezero spring (Fig. 8). It was reported that only 5 samples were ana- lyzed during the breakthrough that last nine days. All other samples were lost (Kranjc 1997). Moreover, pyranine was injected into ponor which is mediocre tracer. For these reasons, we suggest that the expected underground connection between Malo polje and Divje jezero is not reliable, and that water from this area should drain toward Hubelj spring as suggested by the model. In the present case, the transit time seems too long according to the persistence time duration of the tracer (Schudel et al. 2002) and the injected quantity seems underestimated regarding the discharge rate of the two springs, which does not facilitate its recognition. Regarding these factors the reliability of this tracer test is questionable.

Some doubts are also regarding a tracer tests showing connection between Mrzli Log and Podroteja spring (Fig. 8). Pyranine was used. Based on the model, it would be expected that tracer would appear at the Hubelj spring first. Model does not indicate sure connection with Divje jezero and Podroteja springs. For this reason, we attributed the Mrzli Log to catchment of the Hubelj spring.

\section{Water management}

The map showing the distribution of groundwater reservoirs (Fig. 7) is very interesting for water managers. Drilling a borehole in Trnovsko - Banjška planota for supplying water should be carried out only where a groundater reservoir is supposed to be present (blue areas in the model). The approximate depth can also be assessed.

The presence of groundwater reservoirs perched above the level of the main springs may represent an interesting potential for supplying top of the plateau with drinking water (as relatively less energy is required for exploitation and pumping) and also for hydropower production. The latter may become an issue for increasing the production of renewable energy in the future.

The proposed catchment delineations are also important for the protection of water resources for drinking supply. Autogenic/allogenic, and diffluent/confluent recharge areas can be distinguished, and dedicated protection measures can be designed for the respective areas. Groundwater pollution vulnerability assessment methods can be adjusted and can also take the depth of the groundwater bodies given by the model into consideration.

\section{Improvement of the model}

The accuracy of the 3D model is not homogeneous. Ideally much more geological and hydrogeological data should be integrated in order to refine the hydrogeological interpretation provided by the model. Data about deep geological features are particularly scarce and the model could be improved by adding seismic and information from boreholes. However some parts of the 
model seem to be quite liable and could hardly be modified with a completely different geological and hydrogeological interpretation. This is the reason why some dye tracers tests operated in the past have been suspected not to be reliable. We believe that the model provides a rea- sonable sketch of the karst hydrogeology of the Trnovsko - Banjška planota, summarizing the state of knowledge in this area and highlighting parts where complementary works could be performed.

\section{CONCLUSIONS}

The 3D hydrogeological model presented in this paper provides a synthetic, consistent and understandable visualization of the hydrogeological functioning of karst aquifers of the Trnovsko-Banjška planota. KARSYS approach was successfully applied in order to provide this overview as well as a hydrogeological documentation of karst systems in this region. The most important results obtained in the present study are summarized hereafter.

\section{Extension of groundwater reservoirs of the} aquifer (map of groundwater reserves, Fig. 7)

Results show that groundwater is not stored everywhere within the massif. Most groundwater reservoirs (or bodies) are located directly upstream of the main karst springs, however six perched groundwater reservoirs were further identified in the studied area. The map of groundwater reservoirs and the 3D model should be considered before any attempt of groundwater abstraction by drilling of borehole. Volumes of groundwater reserves and potential storage management could be designed based on the model. Therefore, these data are especially of high importance for authorities dealing with water management and water engineering.

\section{Description (localization and type) of the main flows-paths}

Some of the main flow-paths e.g. from a ponor to a spring were sketched in the model. Further ones could be easily drawn. Vadose flow-paths are expected to be close to real conditions, only depending on the precision of the geological 3D model. The exact location of the phreatic flow-paths (i.e the conduits) remains uncertain.

\section{Delineation of catchment areas}

The suggested delineation of catchment areas seems consistent with the observed spring discharge rates, although some of them are not well known (e.g. Mrzlek). The delineation of catchment areas is a necessary step for the management of groundwater resources. These data will be used for establishing a vulnerability map and for delineating protection zones or perimeters for springs used for drinking water supply.

4. The role of regional tectonic on the hydrogeological functioning of the massif

Regional tectonics plays important role for groundwater drainage and storage. Predjama-Avče fault obviously set a limit between Mrzlek and Kajža karst systems. The strike-slip fault also generated the creation of perched groundwater reservoirs that are related depressions associated with the fault. Detailed geological information would be required in order to confirm and closely describe these depressions. Such perched reservoirs could be of interest for hydropower or simply as water resources for settlements located higher than the springs.

\section{A tool for improving water management}

Finally, the results presented in the paper may introduce a useful base for the management of water resource (drinking water, irrigation, hydropower) and/ or water-related problems (e.g floods, land-slides). The model for the first time provides an explicit image of the hydrogeological functioning of the Trnovsko-Banjška planota massif. Hypotheses and data used for sketching the regional hydrogeological model are explicit, making quite easy for anyone to assess the degree of adequacy of any new data with the proposed model. This should encourage water authorities to collect new data and improve the model at some specific locations. The model could then really be used for designing projects, assessing impacts on groundwater, make predictions (e.g. of potential storage or discharge regulation), and support decisions. In other words it should really contribute to improve water management. 


\section{ACKNOWLEDGEMENTS}

The study presented here was carried out in the frame of Slovene-Swiss project financed by Swiss Confederation (so called »Swiss contribution«). Authors thank to Jože
Janež for collecting the data necessary for 3D geological model and to dr. Jože Čar for constructive suggestions.

\section{REFERENCES}

Albreht, A., Habič, P., Janež, J., Kogovšek, J., Kranjc, A., Petrič, M., Rojc, B., Slabe, T. \& M. Štangelj, 1993: Strokovne osnove za zavarovanje vodnih virov in vodnih zalog Trnovsko-Banjške planote. I. faza, unpubl. report, Postojna.

Bakalowicz, M., 2005: Karst groundwater: a challenge for new resources.- Journal of Hydrology, 13, 148-160.

Buser, S., 1986: Osnovna geološka karta SFRJ 1 : 100.000, list Tolmin in Videm (Udine) (Basic geological map of Yugoslavia 1:100,000, sheet Tolmin and Udine). Beograd.

Čar, J., 1997: Geological description.- In: Kranjc, A., (ed.). Karst hydrogeological investigations in Southwestern Slovenia.- Acta carsologica 26, 1, 68-72.

Čar, J., 2010: Geološka zgradba Idrijsko - Cerkljanskega hribovja - Tolmač h geološki karti idrijsko-cerkljanskega hribovja med Stopnikom in Rovtami 1:25000. (Geological structure of the Idrija - Cerkno hills. Explanatory book to the Geological map of the Idrija Cerkno hills between Stopnik and Rovte 1 : 25 000). Geološki zavod Slovenije.

Čar, J. \& Gospodarič, R., 1988: Geološka zgradba in nekatere hidrološke značilnosti bruhalnika Lijaka (Geological setting and some hydrogeological properties of Lijak effluent).- Acta carsologica 17, 3-32.

Čar, J. \& Zagoda, B., 2005: Strukturna lega Habečkovega brezna (Structural position of the Habe shaft Idrijsko Slovenia).- Acta carsologica 34/1, 113-134.

Gospodarič, R. \& P. Habič, 1976: Underground water tracing - investigations in Slovenia 1972 - 1975. Institute for Karst Research SAZU, pp. 309, Ljubljana.

Habe, F. \& Hribar Štefančič, P., 1955: Habečkov brazen.Acta carsologica 1, 25-40.

Habič, P., 1972: Hidrogeološke značilnosti Divjega jezera in njegovega kraškega zaledja. Kulturni in naravni spomeniki Slovenije, 30/7, 7-14, Ljubljana.

Habič, P., 1982: Kraški izvir Mrzlek, njegovo zaledje in varovalno območje (Mrzlek karst spring, its catchment and protection area).- Acta carsologica 10, 45-73.
Habič, P. 1987: Sledilni poskus na kraškem razvodju med Idrijco, Vipavo in Ljubljanico (Water tracing test on the karst watershed among Idrijca, Vipava and Ljubljanica).- Acta carsologica 16, 105-119.

Habič, P. \& J., Čar, 1987: Strokovne osnove za zavarovanje vodnih virov in vodnih zalog Trnovsko-Banjške planote. I. faza. Osnove za določitev varstvenih območij in režimov zavarovanja. Report.

Janež, J., 1992: Hidrogeološke značilnosti kraškega bruhalnika Lijaka.- Rudarsko-metalurški zbornik (Mining and metallurgy quarterly), 39, 1-2, 181192.

Janež, J., 1997: Hydrogeology.- In: Kranjc, A., (ed.). Karst hydrogeological investigations in south-western Slovenia. Acta carsologica 26, 1, 73-81.

Janež, J. \& J. Čar, 1990: Kraški izvir Kajža in njegovo zaledje (Karst spring Kajža and its hydrological background).- Acta carsologica 19, 101-138.

Janež, J., Čar, J., Habič, P. \& R. Podobnik, 1997: Vodno bogastvo Visokega krasa. Geologija d.o.o., pp. 167, Idrija.

Jeannin, P.Y., Eichenberger, U., Sinreich, M., Vouillamoz, A., Malard, A. \& E. Weber, 2012: KARSYS: a pragmatic approach to karst hydrogeological sdystem conceptualisation. Assessment of groundwater reserves and resources in Switzerland.- Environmental Earth Sciences, in press. DOI 10.1007/s12665012-1983-6.

Kranjc, A. (ed.) 1997: Karst hydrogeological investigations in south-western Slovenia. Acta carsologica 26, 1, $388 \mathrm{p}$.

Malard, A., Vouillamoz, A., Weber, E. \& P.Y. Jeannin, 2012: Swisskarst project - toward a sustainable management of karst water in Switzerland. Application to the Bernese Jura. Actes du 13e Congrès National de Spéléologie, Muotathal, Suisse, 29. 11. - 1 . 10. 2012, 215-219.

Mlakar, I. \& Čar, J., 2010: Geološka karta idrijsko - Cerkljanskega hribovja med Stopnikom in Rovtami 1:25.000 (Geological map of the Idrija - Cerkno hills between Stopnik and Rovte 1:25.000). Geološki zavod Slovenije. 
Placer, L., 1981: Geološka zgradba jugozahodne Slovenije (Geologic structure of southwestern Slovenia).Geologija - razprave in poročila 24, 27-60.

Placer, L. \& J. Čar, 1974: Problem podzemeljske razvodnice Trnovskega gozda, Križne gore in Črnovrške planote (The hydrological problematics of the high karst between Idrijca and Vipava Rivers - Trnovski gozd, Križna gora and the plateau of Črni vrh).Acta carsologica 6, 79-93.

Pristov, J., 1997: The climate of the Trnovsko-Banjška planota.- In: Kranjc, A., (ed.). Karst hydrogeological investigations in south-western Slovenia. Acta carsologica 26, 1, 30-38.

Ravbar, N., 2007: The protection of karst waters.- Carsologica 6, ZRC publishing, pp. 254, Postojna-Ljubljana.

Schudel, B., Biaggi, D., Dervey, T., Ross, J.H., Kozel, R. et al., 2002 : Utilisation des traceurs artificiels en hydrogéologie. Guide pratique, unpubl. rep. Office fédéral de l'environnement, Berne, Suisse.
Trček, B., 2003: Epikarst zone and the karst aquifer behaviour : a case study of the Hubelj catchment, Slovenia. Geološki zavod Slovenije, Ljubljana. 100 p.

Turk, J., 2010: Dinamika podzemne vode v kraškem zaledju izvirov Ljubljanice - Dynamics of underground water in the karst catchment area of the Ljubljanica springs.- Carsologica 11, ZRC publishing, pp. 136, Ljubljana.

Vouillamoz, J., Jeannin, P.Y., Demary, S., Weber, E., Malard, A. \& U. Eichenberger, 2011: KARSYS, un concept de caracterisation des systemes karstiques pour une gestion durable des ressources en eau.

Zagoda, B., 2004: Karstification along the thrust contact between the dolomite and limestone in Idrijski Log and Koševnik (Idrijsko, Slovenia) (Zakrasevanje ob narivnem stiku dolomita in apnenca $v$ Idrijskem Logu in Koševniku - Idrijsko, Slovenija).- Acta carsologica $33,2,55-74$. 